\title{
Serpa cheese: Technological, biochemical and microbiological characterisation of a PDO ewe's milk cheese coagulated with Cynara cardunculus $\mathbf{L}$.
}

\author{
Luisa B. ROSEIRO ${ }^{\mathrm{a}, \mathrm{b}}, \mathrm{R}$. Andrew WILBEY ${ }^{\mathrm{b}}$, Manuela BARBOSA ${ }^{\mathrm{a} *}$ \\ a INETI - Instituto Nacional de Engenharia e Tecnologia Industrial \\ DTIA, Estrada do Paço do Lumiar, No. 22, 1649-038 Lisboa, Portugal \\ b School of Food Biosciences, The University of Reading, Reading, RG6 6AP, UK
}

(Received 25 February 2003; accepted 27 May 2003)

\begin{abstract}
Portugal has a strong tradition of cheesemaking from raw ewe's milk; most of these cheeses are still made on a traditional farmhouse scale. Their production is protected by Protected Designation of Origin (PDO) but the specific biochemical aspects of the majority still need to be characterised. Two different cheesemaking procedures, traditional and semi-industrial, were compared technologically, biochemically and microbiologically. It was observed that, despite the highly significant difference between artisanal and semi-industrial cheeses $(P<0.001)$, both products were within the limits of national regulations for most parameters except maturation temperature, humidity and the value for the maturation index. Although the present study was not fully representative of the region, the results obtained suggest that the specific regulations for Serpa cheese should be revised and that other parameters, such as moisture and salt-in-moisture content, which are very much dependent on the cheesemaking process, should be included in order to characterise better this traditional cheese.
\end{abstract}

Serpa cheese characterisation / PDO cheese / ewe's milk cheese / Cynara cardunculus L. / vegetable coagulant

Résumé - Le fromage Serpa : caractérisation technologique, biochimique et microbiologique d'un fromage AOP au lait de brebis, coagulé par Cynara cardunculus L. Le Portugal a une forte tradition dans la fabrication de fromage au lait cru de brebis, continuant à être fabriqués pour la majorité à l'échelle des fermes traditionnelles. La production de quelques-uns de ces fromages est protégée par l'AOP (Appellation d'Origine Protégée) mais leurs caractéristiques spécifiques restent inconnues. Deux procédés de fabrication (artisanal et semi-industriel) ont été réalisés et les résultats obtenus ont été comparés. On a pu observer que, malgré la différence significative des deux procédés de fabrication $(P<0.001)$, tous les deux avaient des valeurs comprises dans les limites imposées par la réglementation. Toutefois, certains paramètres, tels que la température et les conditions d'humidité pendant la maturation, ainsi que les valeurs proposées pour l'index de maturation, étaient différentes. Cela nous conduit donc à suggérer que certains paramètres pourraient être révisés et d'autres tels que l'humidité et le sel dans l'humidité, qui dépendent beaucoup du procédé de fabrication, soient dorénavant inclus afin de permettre une meilleure caractérisation de ce fromage traditionnel.

Caractérisation du fromage Serpa / fromage AOP / fromage au lait de brebis / Cynara cardunculus $\mathbf{L}$. / coagulant végétal

\footnotetext{
* Corresponding author: Manuela.Barbosa@mail2.ineti.pt
} 


\section{INTRODUCTION}

Portugal has a strong tradition of regional cheesemaking, the traditional cheese varieties being made from raw ewe's and goat's milk or from the mixture of both types of milk in various proportions. Many of these cheeses are still made on a farmhouse scale and are traded directly within their production area or to cheese dealers. Despite the dominance of "industrial" pasteurised cow's milk cheese in the market, the farmhouse ewe's and goat's milk cheeses are the most representative of the country and are in strong demand by the consumer. The production of some of these cheeses is now protected either by a Protected Designation of Origin (PDO) or by the Protected Geographic Indication (PGI) [5, 9].

Serpa cheese is an example of an artisanal regional Portuguese cheeses with the PDO designation. Its region of production is a demarcated area in Alentejo, the biggest and driest province of inland Portugal, situated towards the south of the country, between the Tagus and Guadiana rivers. Cheese production plays an important part in the local agricultural economy. Like the other Portuguese PDO cheeses, Serpa cheese is named after a village, perhaps one of the most beautiful in Portugal, on the left side of the river Guadiana.

The origin of Serpa cheese is lost in time. It is believed that it was derived from the equally famous Serra da Estrela cheese, since it has a similar method of production based on the same ingredients, i.e., raw ewe's milk and an aqueous extract of dried cardoon flowers (Cynara cardunculus L.) as coagulant [24, 27]. Furthermore, it has been suggested that this cheese was introduced to the Alentejo by shepherds from Serra da Estrela (a mountainous region in the north of Portugal) during the transhumance periods. The milk for Serra da Estrela cheese is produced by flocks of 40 60 "Bordaleira" ewes under an intensive pasturage exploitation system, the cheese being made almost immediately after milking. However, Serpa cheese milk was tradi- tionally collected from Portuguese "Merino" sheep and flocks could attain more than 600 ewes under an extensive exploitation system [30]. Also, the extent of milking times and the distance between the milking and cheesemaking areas would contribute to a different microflora in the milk. This, together with other factors, resulted in organoleptic characteristics different from those of Serra da Estrela cheese.

Serpa cheese is considered to be one of the best Portuguese cheeses and is mainly artisanally produced, although nowadays some is also produced by a semi-industrial procedure. The main characteristics that distinguish Serpa cheese along with some other PDO Portuguese and Spanish ewe's milk cheeses, and which differentiate them from ewes's milk cheeses from other countries, is their semi-soft texture [25]. This texture is due not only to the type of milk and technology used, but also to the vegetable coagulant, which is highly proteolytic. Serpa cheese is appreciated, not only in its production region, but also all over Portugal. This is also very important for the Baixo Alentejo region from the economical point of view, though only in recent years has attention been drawn to its development and protection by the national authorities, after Portugal's entrance into the EC.

Despite Serpa cheese being one of the most sought-after PDO cheeses in Portugal, little has been done to characterise its production other than a study of the maturation of Serra da Estrela and Serpa cheeses in 1970 [31]. The aim of the present work was to characterise technologically, biochemically and microbiologically two cheesemaking procedures (artisanal and semi-industrial) and to examine how these products relate to the regulations for Serpa cheese.

\section{MATERIALS AND METHODS}

\subsection{Cheese dairies}

After a thorough search within the demarcated region of Serpa cheese, we chose two different dairies in Baixo Alentejo, 

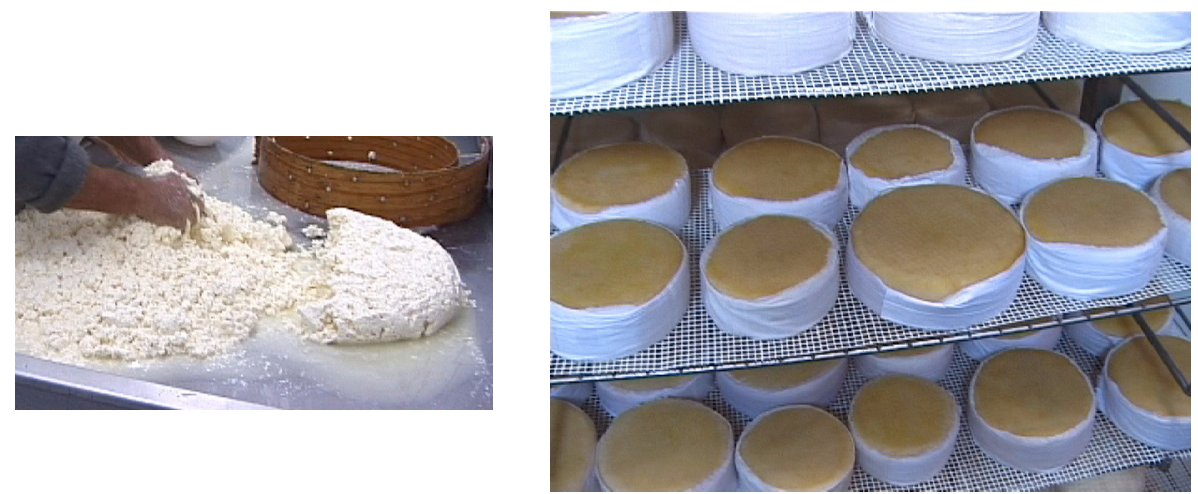

Figure 1. Production of Serpa cheese at dairy B (traditional), showing partially drained curd (left) and partially-matured cheeses (right).

which were the most representative of the traditional and the semi-industrial production, to perform the experimental work. One was a traditional family business, dairy $\mathrm{B}$, where the cheesemaker had been making Serpa cheese for over 50 years and in which about $100 \mathrm{~L}$ of ewe's milk from the Merino breed were transformed into cheese each day, using simple manual technology. The other, dairy $\mathrm{C}$, was a relatively new dairy that produced Serpa cheese using the traditional approach with some improvements of the technology on a semi-industrial scale, employing six women as cheesemakers to transform ca. $1000 \mathrm{~L}$ of Lacaune ewe's milk per day.

This investigation consisted of the manufacture of nine cheeses in each dairy on the same day, according to their own methodology and maturation conditions. The manufacture parameters were recorded. This procedure was repeated three times for each dairy between the months of January and March, corresponding to the peak of production.

\subsubsection{Artisanal manufacture}

\subsubsection{Preparation of the coagulant}

In the artisanal dairy, the amount of dried flowers was calculated empirically by the cheesemaker, e.g. for $50 \mathrm{~L}$ milk, a handful of flowers was used (ca. $30 \mathrm{~g}$ ). These were then soaked in ca. $0.5 \mathrm{~L}$ of cold water, squeezed, and the wet flowers were macerated in a mortar for a while. The macerated flowers were added again to the same water, mixed well and then squeezed from the water that was now of a purplebrownish colour. This aqueous extract was then filtered through a cloth and added to the milk.

\subsubsection{Cheesemaking process}

The milk was collected twice a day by the cheesemaker who purchased it from two local breeders within $10 \mathrm{~km}$ of the village. The milk was immediately transported to the dairy and transformed into cheese. The first step was to warm up the milk to $35^{\circ} \mathrm{C}$ in a water bath, then it was filtered through folded white wool blankets into a clean churn, to remove most of the dirt. Salt (ca. $900 \mathrm{~g} / 50 \mathrm{~L}$ milk) was added to the milk followed by the coagulant prepared just before use, as described above. The milk was left to coagulate for $1 \mathrm{~h}$ while the temperature dropped to ca. $31{ }^{\circ} \mathrm{C}$. Both the amounts of salt and cardoon flower were empirically calculated at the time by the experienced cheesemaker, according to the quantity of milk and the season of the year. 
The coagulum was stirred vigorously in the churn with the help of a wooden stick, until it broke down completely into a smooth grainy mass. This was transferred in small portions into a large mould on the working table. The mould consisted of a perforated flexible wooden strip, that could be formed and tied into a ring, folded and closed at the extremes, so that it could be made smaller while the curd was getting dryer by the draining of the whey. The whey was collected in a vessel at the narrowed end of the working table and could be used later for the production of "Requeijão", a traditional whey cheese that is highly appreciated by itself or used in the local pastry industry, thus also being of great economic benefit for the region.

The curd was worked in this big mould until it became sufficiently dry to be distributed into small round open-ended stainlesssteel moulds (Fig. 1, left). The working and hand pressing was continued in these moulds for a while and then the curd was left to rest. After ca. $1 \mathrm{~h}$, the moulds were turned over and left for another hour. The moulds were turned over again and placed in the maturation room, with a mean temperature of $13{ }^{\circ} \mathrm{C}$ and mean relative humidity (RH) of $90 \%$.

Cheeses were demoulded the next day and turned every day until they were 8-10 d old. At this stage, cheeses were washed with warm diluted whey to control the growth of the surface microflora that naturally forms during this stage of ripening and is characteristic of these cheeses. A white cotton bandage was put around the side to avoid breakage of the fine rind that had started to form on the soft flattening paste. The bound cheeses were then transferred to a second maturation room, which was less humid and warmer, for the second stage of maturation (Fig. 1, right).

The maturation was carried out in an ambient environment, and consequently, at variable values for temperature and humidity depending on the weather conditions (temperatures ranging from $9-17^{\circ} \mathrm{C}$ and
RH ranging from 67-100\% during the minimum $30 \mathrm{~d}$ maturation period). The cheesemaker used his experience in controlling these temperature/RH parameters, by closing or opening screened windows at the dairy. During the experimental period, the ranges of temperature and relative humidity were recorded at the two stages of maturation by a Hygrolog ${ }^{\circledR}$ apparatus that was set to register temperature $\left({ }^{\circ} \mathrm{C}\right)$ and $\mathrm{RH}(\%)$ at hourly intervals. The data were stored and unloaded into proprietary software for further analysis. These cheeses have a seasonal production period that usually goes from late October until the end of May.

\subsubsection{Semi-industrial manufacture}

\subsubsection{Preparation of the coagulant}

The semi-industrial dairy used a similar procedure to prepare the coagulant. Approximately $30-80 \mathrm{~g}$ of flowers were used per $100 \mathrm{~L}$ of milk, depending on a visual assessment of their quality. The weighed flowers were first washed with tap water to take away the gross impurities, then squeezed to remove surplus water. The squeezed wet flowers were placed in an electric blender and comminuted into a brown paste. This paste was added to $250 \mathrm{~mL}$ cold water and well mixed. The flowers were squeezed again and the brownish aqueous extract was filtered through a cotton cloth and added to the milk. This extract was more concentrated than that obtained manually.

\subsubsection{Cheesemaking process}

The milk was obtained by machinemilking from a herd of more than 1800 ewes, and was kept refrigerated in tanks at $4{ }^{\circ} \mathrm{C}$, usually until the next day. From there it was transferred to reception tanks then passed through a heat exchanger where the milk was warmed to $30{ }^{\circ} \mathrm{C}$ and directed to the $1000 \mathrm{~L}$ mechanised water-jacketed vat. At discharge to the vat, the milk was filtered through four white wool blankets that retained the gross impurities. This stage normally took $1.5-2 \mathrm{~h}$ while the bulk of the 
milk was maintained at $30{ }^{\circ} \mathrm{C}$ under gentle stirring. The aqueous extract of the cardoon flowers, prepared while the milk was being filtered, was then added. The coagulation took ca. $1.5-1.75 \mathrm{~h}$. The coagulum was cut with vertical and horizontal knives that circulated around the vat until the small curd grains were ca. $5 \mathrm{~mm}$ in size. The curd was then left to settle for $10 \mathrm{~min}$ and the whey was drained and pumped into a different vat, where it was boiled to make the whey cheese "Requeijão".

After whey drainage, the curd mass was pressed in the vat. All these steps were mechanised but with the assistance of two cheesemakers. The curd was then manually cut into blocks and salted (ca. $5.7 \mathrm{~kg}$ salt per $1000 \mathrm{~L}$ of milk). Two blades were then used to cut the curd and simultaneously mix the salt thoroughly.

Portions of curd were then taken to a working table by the six cheesemakers, who pressed it in white cotton cloths to drain most of the remaining whey. The curd, still inside the cloths, was put into white plastic perforated moulds with a plastic follower. The filled moulds were placed in a hydraulic press at an air feed pressure of $3 \mathrm{~kg} \cdot \mathrm{cm}^{-2}(0.3 \mathrm{MPa})$ for ca. $3.5-4 \mathrm{~h}$, depending on the amount of whey in the cheeses. Approximately 15 cheeses were put into each press. During this period, the cheeses were turned over once and the cloths were withdrawn.

The cheeses were demoulded after pressing and transferred to a maturation chamber, with temperature and humidity controlled at mean values of $10{ }^{\circ} \mathrm{C}$ and $88 \% \mathrm{RH}$, respectively, for $17 \mathrm{~d}$. After that period, the cheeses were transferred to a second chamber, where the temperature was higher and the humidity lower (mean values of $15{ }^{\circ} \mathrm{C}$ and $82 \% \mathrm{RH}$, respectively), and stayed there for 23-28 d. A Hygrolog ${ }^{\circledR}$ apparatus, (Rotronic Instrument Corp., Huntington, New York, USA) was also installed in the two maturation chambers to register the range of temperature and relative humidity during the experimental period. Between these two stages of maturation, the cheeses were washed with water and a white cotton band was placed around the side to avoid deformation of the rind. During the maturation period, cheeses were turned every two days. Cheeses were washed again before going onto the market.

This dairy produces an average of 250 cheeses per day, and although the high season of production is from January to May, it normally produces Serpa cheese all the year round.

\subsection{Sample collection and analysis}

\subsubsection{Sample collection}

Milk, whey and fresh curd were collected at the two dairies on the day of manufacture. During the maturation period, three cheeses were collected after 30,45 and $60 \mathrm{~d}$, respectively, from dairies $\mathrm{B}$ and $\mathrm{C}$, and were weighed and measured before preparation for analysis. This procedure was repeated for each cheesemaking trial.

\subsubsection{Chemical analysis}

Chemical analyses were performed in all milk, whey, fresh curd and cheese samples collected from the two dairies, in order to characterise these products. The methods of analysis used were mainly according to Portuguese standards (NP) or internal methods based on Portuguese and/or IDF standards. Duplicate analyses for each determination were performed.

$\mathrm{pH}$ was determined for all samples by direct measurement using a Metrohm $713 \mathrm{pH}$ Meter (Metrohm Ltd., Herisau, Switzerland). Titrable acidity [11], fat [10], total nitrogen [16], dry matter [12], salt [2] and ash [13] content were also determined for all samples. For nitrogen determination in cheese, a sample was prepared according to the method described in [26]. Ash content in cheese was determined by adapting the standard milk method for the cheese sample preparation. 
Milk and cheese samples were characterised for their main mineral content $(\mathrm{Ca}$, $\mathrm{K}, \mathrm{Mg}$ and $\mathrm{Na}$ ) according to a draft IDF standard [17].

\subsubsection{Microbiological analysis}

A survey was done of the microbiological quality of the milk and the cheese produced by each dairy. Total viable counts (TVC) were done at $30{ }^{\circ} \mathrm{C}$ [14] and lactic acid bacteria (LAB) were enumerated by plate counts [21]. Yeasts and moulds were also enumerated [19]. Presumptive coliforms were enumerated by incubation at $30{ }^{\circ} \mathrm{C}$ [20] with confirmation of Escherischia coli by incubation at $44{ }^{\circ} \mathrm{C}$ [1]. Coagulase positive Staphylococcus aureus were enumerated [18] while Listeria monocytogenes was determined by an enzyme linked fluorescent assay [29].

\subsection{Statistical analysis and data treatment}

Descriptive statistics of the results (namely, average and standard deviation) and analysis of variance (ANOVA) were performed using StatView ${ }^{\circledR}$ 5.0.1 from the SAS Institute Inc. The effect of milk from the dairies $\mathrm{B}$ and $\mathrm{C}$ was evaluated for the microbiological quality and chemical composition of the milk and also for the cheesemaking process throughout the maturation time of the respective cheeses, using the factorial model analysis of variance based on a completely randomised block experimental design. The interaction effect "dairy $x$ maturation of cheeses" for each determination was also determined by evaluating the differences between means at the $95 \%$ level calculated from the residual mean square using Fisher's test.

\section{RESULTS}

B and C cheeses had a flat cylindrical shape with a soft texture, presenting the dimensions for weight, diameter and height
Table I. Composition of raw ovine milk from $\mathrm{B}$ and $\mathrm{C}$ dairies ${ }^{1}$.

\begin{tabular}{lcc}
\hline & $\mathrm{B}$ & $\mathrm{C}$ \\
\hline $\mathrm{pH}($ direct $)$ & $6.75^{\mathrm{a}} \pm 0.05$ & $6.77^{\mathrm{b}} \pm 0.10$ \\
Acidity & $22.1^{\mathrm{a}} \pm 1.7$ & $19.9^{\mathrm{b}} \pm 2.2$ \\
$\left(\mathrm{~cm}^{3} \mathrm{NaOH} \mathrm{N} \cdot \mathrm{dm}^{-3}\right)$ & \multicolumn{3}{c}{ Composition $\left(\mathrm{g} \cdot \mathrm{kg}^{-1}\right)$} \\
& $75^{\mathrm{a}} \pm 16$ & $68^{\mathrm{b}} \pm 8$ \\
Fat & $191^{\mathrm{a}} \pm 21$ & $176^{\mathrm{b}} \pm 18$ \\
Dry Matter & $61.7^{\mathrm{a}} \pm 6$ & $56.9^{\mathrm{b}} \pm 4$ \\
Protein & $9.9^{\mathrm{a}} \pm 1.0$ & $9.2^{\mathrm{b}} \pm 0.4$ \\
Ash & $1.83 \pm 0.26$ & $1.81 \pm 0.16$ \\
$\mathrm{Ca}$ & $0.99 \pm 0.19$ & $0.94 \pm 0.14$ \\
$\mathrm{~K}$ & $0.19^{\mathrm{a}} \pm 0.20$ & $0.17^{\mathrm{b}} \pm 0.30$ \\
$\mathrm{Mg}$ & $0.60 \pm 0.18$ & $0.57 \pm 0.18$ \\
$\mathrm{Na}$ &
\end{tabular}

${ }^{1}$ Means from 23 samples of milk B and 17 samples of milk $\mathrm{C}$ in duplicate. For each determination, means in the same row followed by different letters differ significantly $(P<0.05)$.

at 60-day maturation time of, respectively, $1502 \pm 81 \mathrm{~g}, 19 \pm 0.7 \mathrm{~cm}$ and $5 \pm 0.4 \mathrm{~cm}$ for B cheese and $1261 \pm 41 \mathrm{~g}, 16 \pm 0.4 \mathrm{~cm}$ and $6 \pm 0.8 \mathrm{~cm}$ for $\mathrm{C}$ cheese.

\subsection{Proximate analysis}

\subsubsection{Milk results}

Table I shows the mean results for the composition for 23 samples of raw ovine milk collected in the artisanal dairy (B), and 17 samples collected in the semi-industrial dairy (C) during the experimental work. In most of the analytical parameters (i.e. except $\mathrm{Ca}, \mathrm{K}$ and $\mathrm{Na}$ ) the milks from dairy $\mathrm{B}$ were significantly different from those of dairy $\mathrm{C}$, the most significant differences being for acidity $(P<0.001)$, protein $(P<0.001)$ and ash $(P<0.001)$, all of them higher for milk B.

The average values $\left(\mathrm{cfu} \cdot \mathrm{mL}^{-1}\right)$ for the microbiological quality of 13 samples of raw ovine milk collected from dairy B and 11 samples collected from dairy $\mathrm{C}$ during the experimental work revealed, respectively, for dairies $B$ and $C$, the values of $8.6 \times 10^{6}$ 


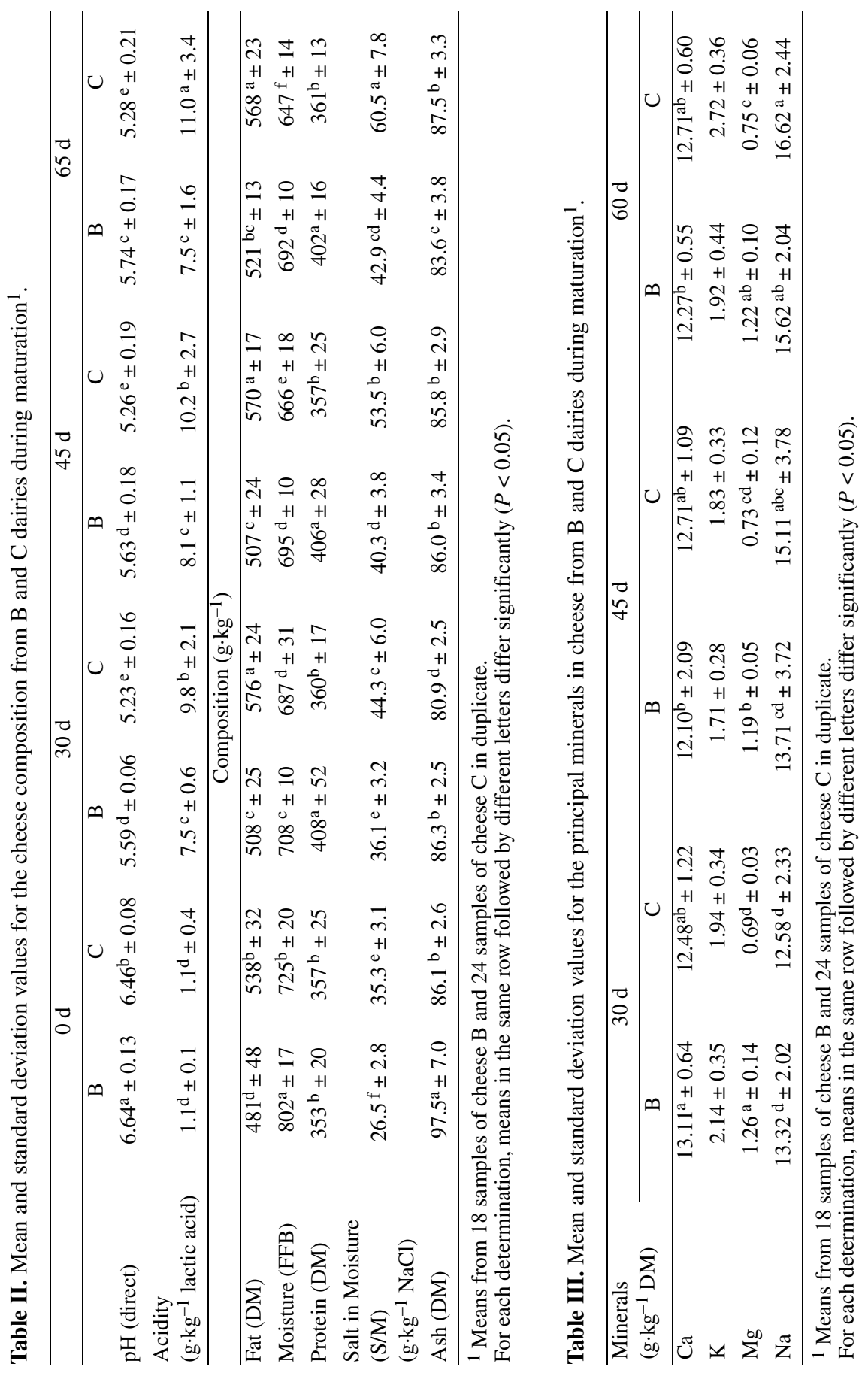


Table IV. Microbiological results of raw ovine milk $\left(\mathrm{cfu} \cdot \mathrm{mL}^{-1}\right)$ and cheese $\left(\mathrm{cfu} \cdot \mathrm{g}^{-1}\right)$ throughout the cheesemaking processes in $\mathrm{B}$ and $\mathrm{C}$ dairies ${ }^{1}$.

\begin{tabular}{|c|c|c|c|c|c|c|}
\hline Determination & Dairy & Milk & $0 \mathrm{~d}$ & $30 \mathrm{~d}$ & $45 \mathrm{~d}$ & $60 \mathrm{~d}$ \\
\hline $\begin{array}{l}\text { Total viable count } \\
\text { at } 30^{\circ} \mathrm{C}\end{array}$ & $\begin{array}{l}\mathrm{B} \\
\mathrm{C}\end{array}$ & $\begin{array}{l}9.5 \times 10^{3} \\
5.0 \times 10^{3}\end{array}$ & $\begin{array}{l}3.0 \times 10^{9} \\
5.0 \times 10^{6}\end{array}$ & $\begin{array}{l}7.8 \times 10^{8} \\
5.6 \times 10^{8}\end{array}$ & $\begin{array}{l}2.1 \times 10^{9} \\
6.3 \times 10^{8}\end{array}$ & $\begin{array}{l}8.6 \times 10^{8} \\
4.6 \times 10^{8}\end{array}$ \\
\hline $\begin{array}{l}\text { Lactic acid } \\
\text { bacteria }\end{array}$ & $\begin{array}{l}\mathrm{B} \\
\mathrm{C}\end{array}$ & $\begin{array}{l}8.5 \times 10^{2} \\
9.3 \times 10^{3}\end{array}$ & $\begin{array}{l}4.8 \times 10^{8} \\
8.6 \times 10^{5}\end{array}$ & $\begin{array}{l}1.5 \times 10^{8} \\
2.5 \times 10^{8}\end{array}$ & $\begin{array}{l}4.0 \times 10^{8} \\
4.1 \times 10^{8}\end{array}$ & $\begin{array}{l}5.6 \times 10^{8} \\
1.6 \times 10^{8}\end{array}$ \\
\hline Coliforms & $\begin{array}{l}\mathrm{B} \\
\mathrm{C}\end{array}$ & $\begin{array}{c}1 \\
15\end{array}$ & $\begin{array}{l}3.8 \times 10^{2} \\
5.5 \times 10^{5}\end{array}$ & $\begin{array}{l}6.8 \times 10^{5} \\
1.5 \times 10^{5}\end{array}$ & $\begin{array}{l}5.1 \times 10^{6} \\
7.9 \times 10^{4}\end{array}$ & $\begin{array}{l}1.1 \times 10^{6} \\
6.3 \times 10^{4}\end{array}$ \\
\hline E. coli & $\begin{array}{l}\mathrm{B} \\
\mathrm{C}\end{array}$ & $\begin{array}{l}1 \\
1\end{array}$ & $\begin{array}{l}1.2 \times 10^{2} \\
0.9 \times 10^{2}\end{array}$ & $\begin{array}{l}3.1 \times 10^{4} \\
1.4 \times 10^{3}\end{array}$ & $\begin{array}{l}8.7 \times 10^{4} \\
1.8 \times 10^{3}\end{array}$ & $\begin{array}{l}1.6 \times 10^{5} \\
1.2 \times 10^{3}\end{array}$ \\
\hline $\begin{array}{l}\text { Staph. aureus } \\
\text { (coagulase positive) }\end{array}$ & $\begin{array}{l}\mathrm{B} \\
\mathrm{C}\end{array}$ & $<10^{-}$ & $\begin{array}{l}<10 \\
<10^{4}\end{array}$ & $<10^{4}$ & $<10^{-}$ & $<10^{-}$ \\
\hline $\begin{array}{l}\text { Listeria } \\
\text { monocytogenes } \\
(25 \mathrm{~mL} \text { or } 25 \mathrm{~g})\end{array}$ & $\begin{array}{l}\mathrm{B} \\
\mathrm{C}\end{array}$ & - & - & - & - & - \\
\hline Yeasts & $\begin{array}{l}\mathrm{B} \\
\mathrm{C}\end{array}$ & $\begin{array}{l}2.1 \times 10^{2} \\
8.9 \times 10^{3}\end{array}$ & $\begin{array}{l}4.4 \times 10^{5} \\
1.1 \times 10^{4}\end{array}$ & $\begin{array}{l}1.3 \times 10^{5} \\
2.3 \times 10^{3}\end{array}$ & $\begin{array}{l}7.2 \times 10^{2} \\
1.1 \times 10^{4}\end{array}$ & $\begin{array}{l}1.1 \times 10^{3} \\
2.9 \times 10^{2}\end{array}$ \\
\hline
\end{tabular}

${ }^{1}$ Mean results for duplicate determinations.

and $1.4 \times 10^{5}$ for the total viable count at $30{ }^{\circ} \mathrm{C}$ (TVC); $2.6 \times 10^{3}$ and $6.7 \times 10^{4}$ for the lactic acid bacteria count (LAB); $6.5 \times 10^{2}$ and $1.1 \times 10^{2}$ for the coliforms count; 56.6 and 1.4 for E. coli count. Listeria monocytogenes was not detected in a $25 \mathrm{~mL}$ sample for all samples.

There was no significant difference in hygienic quality between the milks, despite milk $\mathrm{C}$ being obtained by machine-milking and milk B by hand-milking in the field. A significant difference was found in the naturally-occurring lactic acid bacteria count $(P<0.001)$, being higher in milk $\mathrm{C}$.

Presumptive coliform counts were low but variable, without significant difference between the milk sources. A small proportion of these counts were confirmed as E. coli.

\subsubsection{Cheese results}

The composition of the cheese throughout maturation and the mineral content are shown in Tables II and III, respectively.

The results for temperature and relative humidity were recorded by the Hygrolog ${ }^{\circledR}$ in each of the dairies throughout the maturation period. These observations resulted in mean values for ripening temperature of $13.5 \pm 1.7^{\circ} \mathrm{C}$ and $12.5 \pm 3.5^{\circ} \mathrm{C}$; and mean values for relative humidity of $89.9 \pm 6.9 \% \mathrm{RH}$ and $85.2 \pm 5.2 \% \mathrm{RH}$, respectively, for dairies $\mathrm{B}$ and $\mathrm{C}$.

One cheesemaking trial was chosen randomly at each of the dairies to evaluate the microbiological quality throughout the procedure of cheesemaking. The results are shown in Table IV.

Though the transformation of milk to curd in dairy B was accompanied by a greater rise in TVC, it would appear that this was due to the growth of the endogenous $\mathrm{LAB}$ since no starter addition is used for this type of cheese. From $30 \mathrm{~d}$ maturation onwards there was practically no difference in the microbial counts between cheeses from the two dairies, except for yeasts. Moulds were not detected in either of the dairies' products at any stage. Coliforms and $E$. coli were practically absent in milk from both dairies, but present in curd and cheese throughout maturation. The presence 
Table V. Specifications for Serpa cheese and corresponding results for B and C cheeses.

\begin{tabular}{lccc}
\hline & Decree No. 39/87 [6] & B & C \\
\hline Milk & Pure raw ovine milk & Yes & Yes \\
Coagulant & $\begin{array}{c}\text { Aqueous extract from } \\
\text { C. cardunculus L. }\end{array}$ & Yes & Yes \\
Whey drainage & Slow & overnight & in press (3.5-4 h) \\
Maturation time & 30 d (minimum) & Yes & $45 \mathrm{~d}($ minimum) \\
Maturation temperature $\left({ }^{\circ} \mathrm{C}\right)$ & $6-12$ & $13.5 \pm 1.7$ & $12.5 \pm 3.5$ \\
Maturation relative humidity $(\%)$ & $85-90$ & $89.9 \pm 6.9$ & $85.2 \pm 5.2$ \\
Moisture (FFB) $(\%)$ & $61-69$ & $\$ 70.8 \pm 1.0$ & $\$ 66.6 \pm 1.8$ \\
Fat (DM) $(\%)$ & $45-<60$ & $\$ 50.8 \pm 2.5$ & $\$ 57.0 \pm 1.7$ \\
Maturation index & 45 (minimum) & $\$ * 34(\mathrm{pH} 4.4-\mathrm{SN} / \mathrm{TN})$ & $\$ * 29(\mathrm{pH} 4.4-\mathrm{SN} / \mathrm{TN})$ \\
\hline
\end{tabular}

¥ At time of sale from each dairy. * Roseiro et al. [26].

of $S$. aureus in dairy $\mathrm{C}$ was considerably high, in contrast with dairy B where $S$. aureus were practically absent.

\section{DISCUSSION}

The specifications for Serpa cheese and the corresponding results obtained for B and $\mathrm{C}$ cheeses are shown in Table V. The breed of sheep is not specified but may have an effect. It can be seen from this table that values of cheeses $\mathrm{B}$ and $\mathrm{C}$ for parameters such as maturation temperature, relative humidity and the index of proteolysis previously determined [26] do not agree with the specifications described in the Serpa cheese decree [6].

Despite the differences between cheeses $\mathrm{B}$ and $\mathrm{C}$, both are within the dimension limits of normal Serpa cheese. These used to be bigger, but the recent market tendency is towards a cheese of ca. $1 \mathrm{~kg}$, which certainly affects the maturation and typicity of the cheese.

\subsection{Milk results}

The differences between milk $\mathrm{B}$ and milk $\mathrm{C}$ were probably due to specific genetic characteristics of the two breeds, milking and feeding systems. The Merino breed produces low quantities of milk which is richer in its composition [23] than that from other, more productive, breeds such as Lacaune. Additionally, free-grazing animals in the fields all day tend to produce a richer milk, in terms of fat and protein, than animals that spend part of the day indoors and eat concentrated feed. Skilled shepherds also know which herbs and plants give off-flavours to the milk and consequently to cheese, and avoid leaving their animals in fields where these herbs grow. It also appears that hand-milking extracts more milk, especially towards the end of milking, while machine-milking tends to leave a certain amount of residual milk in the udder, which normally is more concentrated [3].

In a similar investigation of raw ovine milk used in the manufacture of raw ovine milk cheeses, Gomez et al. [15] found counts $\left(\mathrm{cfu} \cdot \mathrm{mL}^{-1}\right)$ of $7.1 \times 10^{5}$ for TVC and $2.0 \times 10^{4}$ for coliforms. These figures were very similar for TVC but higher for coliforms when compared with the ones for Serpa milk. Thus, these Portuguese raw ovine milks can be regarded as being of a superior microbiological quality. The immediate refrigeration of milk $\mathrm{C}$ after milking and 
the minimal delay between milking and cheesemaking for milk B may be regarded as contributory factors.

\subsection{Cheese results}

The highly significant differences $(P<$ 0.001 ) observed for certain parameters (fat, dry matter and moisture in fat-free basis, salt-in-moisture and ash) between curds from the two dairies were naturally related to differences in both the milks and cheesemaking practices in the dairies. Whey drainage was aided by manual manipulation of curd in dairy $\mathrm{B}$, while in dairy $\mathrm{C}$ both the cutting of the curd and whey drainage were mechanised. This resulted in a higher loss of fat to whey (data not shown), leaving a lower level of fat in dry matter (FDM) in curd from dairy B in comparison with dairy $\mathrm{C}$, despite the higher fat level in the milk. However, losses of protein and/or fat into the whey are not considered a major cheese yield problem. All the whey obtained as a by-product of the cheesemaking is traditionally used for the production of "Requeijão", a whey cheese made by simply boiling the whey and scooping the heat-precipitated protein (together with fat and the fines from curd) into a cotton cloth, which is hung and left to drain.

Differences in pressing techniques also led to dry matter (DM) being considerably higher in curd C. Protein in dry matter, however, showed no significant difference between the two curds. Salt-in-moisture (S/M) and ash were also significantly higher in curd $\mathrm{C}(P<0.001)$, this difference being related to the amount of salt used and the salting procedures in the dairies (dairy $\mathrm{B}$ added salt to the milk before cheesemaking, while dairy $\mathrm{C}$ added salt directly to the curd after whey drainage).

Overall, there was a highly significant difference $(P<0.001)$ between cheeses from the two dairies. The metabolism of residual lactose in the curd reduced the $\mathrm{pH}$ of the cheeses to minima at $30 \mathrm{~d}$, the slight upward drift thereafter being attributable to proteolysis and to lactate metabolism by the yeasts. A similar pattern was observed for titrable acidity, where differences in protein also contributed to variation between cheeses. Differences in storage conditions will also have an effect; Carmona et al. [4] observed that similar ewe's milk cheeses matured in a controlled chamber exhibited higher lactic acid levels than those stored under ambient conditions. Moisture, fat and FDM were also significantly different $(P<0.001)$ between $\mathrm{B}$ and $\mathrm{C}$ cheeses. S/M values were significantly higher $(P<0.001)$ in $\mathrm{C}$ cheeses throughout maturation. Most of the salt added to the milk in B was lost in whey, while at dairy $C$ the salt was added to the curd after whey drainage. The higher initial moisture combined with lower S/M for cheeses from dairy B contributed to a higher percentage of moisture loss during maturation, $23 \%$ compared with $19.5 \%$ for cheeses from dairy $\mathrm{C}$.

$\mathrm{B}$ and $\mathrm{C}$ cheeses were also within the limits for fat-in-dry matter set by the regulations for Serpa cheese [6], though some other parameters do not agree with these specifications. Some differences between the cheeses may be attributable to the different ewe's milks used, coming from both different sources and different breeds.

The ash content in the cheese was influenced by the salt added and those mineral components retained from the milk. The calcium, sodium and potassium levels in dry matter showed no significant difference between cheeses $\mathrm{B}$ and $\mathrm{C}$ throughout maturation, but magnesium in dry matter was significantly higher in B cheeses $(P<$ 0.001). Sanjuán et al. [28] determined the content of minerals in Los Pedroches cheese, a Spanish Merino ewe's milk cheese also coagulated with Cynara cardunculus L. They obtained results for $\mathrm{Ca}, \mathrm{K}$ and $\mathrm{Na}$ in dry matter for cheeses at 30, 43 and $60 \mathrm{~d}$ ripening similar to those presented in Table III; the results for $\mathrm{Mg}$ in dry matter were closer to those obtained for $\mathrm{C}$ cheeses. The higher results obtained for $\mathrm{Mg}$ in $B$ cheeses might be due to genetic characteristics of the milk or to the composition 
of the feed, since the Mg level was also significantly higher in the milk (Tab. I).

Dairy C showed a considerable presence of $S$. aureus in milk and throughout cheese maturation in comparison with dairy B. This may be an indirect result of machinemilking, which is associated with a higher incidence of mastitis. The presence of $S$. aureus in cheese is not desirable because high levels of coagulase-positive enterotoxin-producing strains may lead to food poisoning. Listeria monocytogenes was not detected in a $25 \mathrm{~g}$ sample for all samples from both dairies.

Consideration must also be given to the possible contamination of the cardoon extracts used as coagulants. Gomez et al. [15] obtained similar results for TVC and coliforms in curd and cheese from raw ovine milk using Cynara L. as coagulant at 30 and $60 \mathrm{~d}$ maturation. However, when these results were compared with similar cheeses made with animal rennet, they concluded that considerable contamination had originated from highly contaminated cardoon extracts.

A highly significant difference $(P<$ 0.001) was also observed for ripening temperature and relative humidity conditions between the two dairies. These differences would contribute to the development of the different microflora and to differences in moisture losses between the two dairies. The specified values for temperature and relative humidity were difficult to attain, especially for the B cheeses, which were matured in ambient conditions.

It should also be noted that the decree does not specify the method for measuring the maturation index. Assuming that the maturation index was based on the percentage of nitrogen soluble in water, then this minimum value for the maturation index was not achieved by the percentage of nitrogen soluble at $\mathrm{pH} 4.4(\mathrm{pH} 4.4-\mathrm{SN} / \mathrm{TN})$ at the maturation time of $30 \mathrm{~d}$, as could be observed from the results obtained for the evaluation of proteolysis for these cheese samples previously published [26]. In the experiments described here, the minimum " 45 " value established was achieved for $\mathrm{B}$ cheese at $60 \mathrm{~d}$ maturation time, while the $\mathrm{C}$ cheese only achieved a mean proteolysis index of 31 . This value is very much dependent on the cheesemaking procedure and maturation conditions, which have undergone variations for this type of cheese for decades, namely with the introduction of maturation chambers. These considerations lead to the suggestion that Serpa cheese should have a minimum maturation time of $60 \mathrm{~d}$, in order to achieve the ideal state of maturity. This would imply not only greater safety, bearing in mind that it is a raw milk cheese, but also an improvement in the organoleptical characteristics. According to those results, there should be a more detailed study of the maturation index based on the percentage of nitrogen soluble at $\mathrm{pH} 4.4$ in order to establish a more accurate minimum value, consistent with good cheesemaking practice and satisfactory sensory properties for the consumer.

Additionally, the results obtained from the two dairies studied also suggested that a revision of the specifications in the regulations for Serpa cheese should be considered, since a certain degree of heterogeneity is also characteristic of Serpa cheese. This variability has also been observed for other similar cheeses, e.g. La Serena cheese, produced with Cynara cardunculus L. as coagulant $[7,8]$. The heterogeneity of the vegetable coagulant, differences in the cheesemaking procedures between dairies, and use of raw milk with high total counts and no added starter culture, lead to some variations between cheeses. These are, like other similar cheeses, traditional products, linked to a geographic origin and local knowhow which cannot be reproduced exactly in another place, thus contributing to the preservation of a natural diversity of flavours and to the variety of cheeses.

This investigation has highlighted the need for a more detailed study of the maturation of Serpa cheese. Such a study should be complemented by an evaluation 
and definition of the sensory and rheological properties of the cheese. The study of the specific cheese flora during ripening can also be an important factor [22]. Such work would be consistent with development of the concept of PDO products, which is a significant factor in maintaining both variety and quality in food production within Europe.

It is also considered important that other parameters, which have a relevance to measurement of proteolysis, should be included in the cheese specifications, namely moisture and salt-in-moisture content.

Aknowledgements: The authors are indebted to the cheesemakers at dairies B and C in the Demarcated Region of Serpa cheese, for their invaluable collaboration and support.

Special thanks are due to F. Ravasco, S. Pinto and C. Marrocos for their collaboration in sample preparation and chemical analyses and to H. Cordeiro (UMA), M.J. Borges (UBAI) and C. Neves (UQA) for, respectively, performing microbiological, mineral, salt and ash analyses, and to their respective coordinators.

The authors are grateful to the "Fundação para a Ciência e Tecnologia, Ministério da Ciência e do Ensino Superior" (FCT/MCES), for their sponsorship of this project (POCTI 35257/2000) and the Ph.D. fellowship for L.B. Roseiro. Part of the work was also sponsored by a British Council grant.

\section{REFERENCES}

[1] AFNOR, Microbiologie alimentaire. Dénombrement des Escherichia coli $\beta$-glucuronidase positive par comptage des colonies à $44{ }^{\circ} \mathrm{C}$. Méthode de routine. Standard NFV08-053, Paris, France, 1993.

[2] AOAC 16.272, Chloride (total) in cheese. Official Methods of Analysis of the Association of Official Agricultural Chemists, 14th Edition Washington, D.C., USA, 1984, p. 310.

[3] Belo A.T., Influência das reservas corporais e da suplementação azotada na produção de leite de ovelhas alimentadas com erva. Estudo de parâmetros indicadores do metabolismo no inicio da lactação. Ph.D. thesis, Instituto Superior de Agronomia, Universidade Técnica de Lisboa, Portugal, 2000.
[4] Carmona M.A., Sanjuán E., Gómez R., Fernández-Salguero J., Effect of starter cultures on the physico-chemical and biochemical features in ewe cheese made with extracts from flowers of Cynara cardunculus L., J. Sci. Food Agric. 79 (1999) 737-744.

[5] CEE, Conselho de 14 de Julho de 1992. Regulamento relativo à protecção das indicações geográficas e denomonações de origem dos produtos agrícolas e dos géneros alimentícios. J. Commun. Eur. No. 208 L de 24 de Julho (1992) pp. 1-8.

[6] Decreto Regulamentar, DR No. 39/87. Diário da República No. 1146 de 29 de Junho de 1987, I SÉRIE, 2499-2500.

[7] del Pozo B.F., Gaya P., Medina M., RodríguezMarin M.A., Nuñez M., Changes in chemical and rheological characteristics of $\mathrm{La}$ Serena ewes' milk cheese during ripening, J. Dairy Res. 55 (1988) 457-464.

[8] del Pozo B.F., Gaya P., Medina M., RodríguezMarin M.A., Nuñez M., Changes in the microflora of La Serena ewes' milk cheese during ripening, J. Dairy Res. 55 (1988) 449-455.

[9] DGDR-Produtos Agrícolas e Géneros Alimentícios com Denominação de Origem Protegida, com Indicação Geográfica Protegida ou com Certificado de Especialidade, Divisão da Promoção de Produtos de Qualidade, $26^{\mathrm{a}}$ Edição, Ministério da Agricultura, do Desenvolvimento Rural e das Pescas, Lisboa, Portugal, 1999, pp. 1-21.

[10] DGQ, Leites: Determinação da Matéria Gorda (Técnica de Gerber) Processo Corrente. Standard NP 469, Lisboa, Portugal, 1983.

[11] DGQ, Leites: Determinação da Acidez. Standard NP 470, Lisboa, Portugal, 1983.

[12] DGQ, Leites: Determinação do resíduo seco e resíduo seco isento de matéria gorda. Standard NP 475, Lisboa, Portugal, 1983.

[13] DGQ, Leites: Determinação da cinza total. Standard NP 477, Lisboa, Portugal, 1983.

[14] DGQ, Microbiologia Alimentar. Regras gerais para a contagem de microrganismos a $30{ }^{\circ} \mathrm{C}$. Standard NP 1995, Lisboa, Portugal, 1982.

[15] Gomez R., Sanchez E., Vioque M., Ferreira J., Tejada J., Fernandez-Salguero J., Microbiological characteristics of ewe's milk cheese manufactured using aqueous extracts from various species of cardoon Cynara L., Milchwissenschaft 56 (2001) 16-19.

[16] IDF, Milk - Determination of Nitrogen content. Part 1: Kjeldahl method and Part 2: Block-digestion method (Macro method), Standard 20B, Int. Dairy Fed., Brussels, Belgium, 1993. 
[17] IDF, Milk and Milk Products. Determination of calcium, sodium, potassium and magnesium contents. Atomic absorption spectrometric method. Draft Project, Int. Dairy Fed., Brussels, Belgium, 2000.

[18] IPQ, Microbiologia Alimentar. Regras gerais para a pesquisa de Staphylococcus aureus. Standard NP 2260, Lisboa, Portugal, 1986.

[19] IPQ, Microbiologia Alimentar. Contagem de bolores e leveduras. Parte 1: Incubação a $25^{\circ} \mathrm{C}$. Standard NP 3277-1, Lisboa, Portugal, 1987.

[20] IPQ, Microbiologia Alimentar. Regras gerais para a contagem de bactérias coliformes a $30^{\circ} \mathrm{C}$. Standard NP 3788, Lisboa, Portugal, 1990.

[21] ISO/DIS, Microbiology of food and animal feeding stuffs - Enumeration of lactic acid bacteria - Colony-count technique at $30^{\circ} \mathrm{C}$. Draft International Standard 15214, International Standards Organisation, Geneva, Switzerland, 1996.

[22] Linden G., Chamba J.F., La typicité des fromages : une réalité, un objectif, Sci. Aliments 14 (1994) 573-580.

[23] Nuñez M., del Pozo B.F., Rodríguez-Marin M.A., Gaya P., Medina M., Effect of vegetable and animal rennet on chemical, microbiological, rheological and sensory characteristics of La Serena cheese, J. Dairy Res. 58 (1991) 511-519.

[24] Roseiro M.L.B., Ewe's milk cheesemaking in Portugal using a vegetable rennet (a review), Sheep Dairy News 8 (1991) 74-75.
[25] Roseiro M.L.B., Barbosa M., Portuguese artisanal cheeses, in: European Commission (Ed.), Artisanal European Cheeses, Science Research Development, Brussels, Belgium, 1996, pp. 79-92.

[26] Roseiro L.B., Garcia-Risco M., Barbosa M., Ames J.M., Wilbey R.A., Evaluation of Serpa cheese proteolysis by nitrogen content and capillary zone electrophoresis, Int. J. Dairy Technol. 56 (2003) 99-104.

[27] Roseiro L.B., Barbosa M., Ames J.M., Wilbey R.A., Cheesemaking with vegetable coagulants - the use of Cynara L. for the production of ovine milk cheeses, Int. J. Dairy Technol. 56 (2003) 76-85.

[28] Sanjuán E., Saavedra P., Millán R., Castello M., Fernández-Salguero J., Effect of ripening and type of rennet on the mineral content of Los Pedroches cheese, J. Food Qual. 21 (1998) 187-200.

[29] VIDAS ${ }^{\circledR}$ Listeria monocytogenes II (LMO2), Detection of Listeria monocytogenes in food products using the ELFA technique BioMérieux Inc., Lyon, France, 2001.

[30] Vieira-de-Sá F., Barbosa M., O Leite e os Seus Produtos, Nova Colecção Técnica Agrária 5, Clássica Editora, $5^{a}$ Edição, Lisboa, Portugal, 1990.

[31] Vieira-de-Sá F., Machado B.R., Pinto O.P.R., Cruz I.M.V., Carneiro M.J.D., Barbosa M.M.A., Reis M.M.C., Maturação em Queijo de Ovelha - Serra e Serpa, INII Química e Biologia 6 - Instituto Nacional de Investigação Industrial, Lisboa, Portugal, 1970.

To access this journal online: www.edpsciences.org 